\title{
PENINGKATAN PENGUASAAN MATERI MEMBACA DAN \\ MEMBUAT KALIMAT MELALUI MEDIA GAMBAR DUA \\ DIMENSITEMA KEGIATANKU PADA SISWA KELAS 1 \\ SD NEGERI BANJARAN
}

\begin{abstract}
Oleh: Rohaeti
ABSTRAK

Tujuan penelitian ini adalah untuk meningkatkan pembelajaran di kelas 1, untuk mengkaji kendala yang dihadapi guru dalam menerapkan pembelajaran dan untuk mencari solusi yang tepat dalam mengatasi kendala yang dihadapi guru adalah dalam Peningkatan Penguasaan Materi Membaca dan Membuat Kalimat Melalui Media Gambar Dua Dimensi Tema Kegiatanku pada Siswa Kelas 1 SD Negeri Banjaran. Melalui Media Gambar Dua Dimensi dapat meningkatkan hasil belajar siswa kelas 1 SD Negeri Banjaran. Variabel yang menjadi sasaran pembelajaran dalam penelitian tindakan kelas ini adalah hasil belajar Kelas $1 \mathrm{SD}$ Negeri Banjaran. Bentuk penelitian ini adalah tindakan kelas dengan model siklus. Tiap siklus terdiri dari beberapa tahapan, yaitu: perencanaan, pelaksanaan tindakan. observasi dan refleksi. Sebagai populasi adalah siswa kelas 1 SD Negeri Banjaran yang berjumlah 25 orangsiswa . Teknik pengumpulan data variable pengumpulan data variabel peningkatan hasil belajar adalah observasi, pencatatan arsip dan dokumen, dan tes perekaman . Teknik melalui data yang digunakan. Berdasarkan hasil penelitian dapat disimpulkan bahwa tindakan kelas pada siklus II menunjukkan adanya peningkatan dibanding sebelum tindakan sebelumnya. Dengan demikian dapat diajukan suatu rekomendasi bahwa pembelajaran membaca dan membuat kalimat melalui media gambar dua dimensi pada siswa kelas 1 SD Negeri Banjaran tahun ajaran 2015/2016 bisa meningkatkan prestasi belajar.
\end{abstract}

Kata Kunci : Meningkatkan, Prestasi, Belajar, Media Gambar Dua Dimensi 


\section{Pendahuluan}

Salah satu permasalahan pendidikan yang dihadapi oleh siswa kelas satu SD Negeri Banjaran adalah pembelajaran Bahasa Indonesia, hal ini terutama terbukti dari penguasaan materi dari hasil evaluasi yang masih rendah, juga selalu kalah dalam perlombaan Calistung tingkat kabupaten.Kurangnya percaya diri dalam mengeluarkan pendapat, karena hanya beberapa anak saja yang mampu membaca terutama membaca teknis.

Guru sebagai salah satu komponen penting sekolah harus memiliki kemampuan profesional yang memadai agar mampu mencapai tujuan Pendidikan Nasional. Guru tidak berarti apa- apa tanpa kehadiran peserta didik (siswa).

Upaya peningkatan mutu pendidikan haruslah dilakukan dengan menggerakkan seluruh komponen yang menjadi sub system dalam suatu system mutu pendidikan. Sub system yang pertama dan utama dalam peningkatan mutu pendidikan adalah guru. Di tangan gurulah hasil pembelajaran yang merupakan salah satu indikator mutu pendidikan lebih banyak ditentukan, yakni pembelajaran yang baik seikaligus bernilai sebagai pemberdayaan kemampuan (ability) dan kesanggupan (capability) peserta didik. Tanpa guru yang dapat dijadikan andalannya, mustahil suatu system pendidikan mendapat hasil sebagaimana diharapkan. Mutu pendidikan ditentukan dalam kelas melalui PBM. Oleh karena itu, upaya untuk memperbaiki dan meningkatkan mutu pendidikan khususnya Peningkatan penguasaan materi membaca dan membuat kalimat, mencoba dengan cara penyajian pembelajaran pada anak melalui media gambar gambar dua dimensi, karena pada anak seusia kelas satu masih senang pada gambar. Metode cara baru dalam pembelajaran ini diharapkan mampu meningkatkan penguasaan materi membaca dan membuat kalimat.
Memperbaiki pembelajaran terutama pembelajaran Bahasa Indonesia di SD Negeri Banjaran merupakan tujuan utama dari penelitian tindakan kelas ini.

Berdasarkan uraian dan temuan peneliti (guru), mata pelajaran Bahasa Indonesia seperti yang disebutkan di atas, dapat dipetakan permasalahanpermasalahan yang dihadapi guru adalah:

1. Siswa SD Negeri Banjaran kurang bergairah dalam pembelajaran /kurang memperhatikan guru yang sedang menerangkan.

2. Penanda utama kekuranggairahan siswa tersebut dalam pembelajaran Bahasa Indonesia adalah rendahnya partisipasi dan inisiatif siswa selama proses pembelajaran berlangsung.

3. Kurangnya keberanian mengemukakan pendapat (mengacungkan tangan) termasuk tidak berani tampil didepan kelas.

4. Guru belum maksimal menggunakan media dan strategi pembelajaran yang bervariasi.

5. Guru membutuhkan strategi pembelajaran yang dapat meningkatkan kegairahan siswa dalam pembelajaran Bahasa Indonesia sehingga dapat meningkatkan kemampuan berbicara siswa.

Jika dicermati secara seksama, akar permasalahan di atas adalah kurangnya kemampuan menguasai materi bahasa Indonesia termasuk kurangnya keberanian siswa untuk tampil di muka kelas. Dan ketika akan lomba CALISTUNG juga terjadi siwa yang menangis karena kurangnya percaya diri . Karena itu, masalah utama yang perlu segera dicarikan pemecahannya adalah bagaimana meningkatkan aktivitas penguasaan materi oleh siswa pada mata pelajaran Bahasa Indonesia agar terjadi interaksi positif dalam pembelajaran yang sekaligus dapat meningkatkan hasil belajar siswa baik menggunakan media gambar dua dimensi.Diharapkan siswa setelah materi 
pelajaran sudah dikuasai maka siswa akan lebih mampu melakukan komunikasi sebagai bekal dalam kehidupan social berbangsa dan bernegara dan bila besar nanti atau dalam jangka panjang akan menjadi anak yang dapat menggunakan bahasa Indonesia yang baik dan benar sesuai dengan kaidah bahasa Indonesia .

Bagaimana meningkatkan aktivitas penguasaan materi membaca oleh siswa kelas 1 semester 1 SD Negeri Banjaran pada mata pelajaran Bahasa Indonesia dengan media gambar dua dimensi ? Bagaimana meningkatkan pemahaman siswa kelas 1 semester 1 SD Negeri Banjaran pada mata pelajaran Bahasa Indonesia dengan media gambar dua dimensi?

\section{Kajian Teori}

\section{Aktivitas penguasaan materi membaca}

Brooks dalam Tarigan mengatakan bahwa membaca intensif adalah studi seksama, telaah teliti dan penanganan terperinci yang dilaksanakan di dalam kelas terhadap suatu tugas yang pendek kira- kira dua sampai empat halaman setiap hari. Saya sangat setuju sekali dengan pendapat beliau karena sangat relevan dengan salah satu program pemerintah untuk program literasi.

Yaitu 15 menit sebelum pelajaran dimulai siswa SD Negeri Banjaran khususnya kelas 1 melakukan aktivitas membaca yang tentunya dilengkapi dengan media gambar dua dimensi. Caranya siswa melakukan aktivitas membaca dengan cara sehari sebelumnya mencari buku di perpustakaan tapi, yang dibacanya berupa buku cerita (fiksi) supaya terdapat gambarnya, hal ini sangat sesuai dengan PTK yang saya teliti. Aktivitas yang lainnya guru menyiapkan bahan untuk mensukseskan program LITERASI dengan cara mencari cerita fiksi yang ada pada buku pelajaran yang terdapat pada referensi buku mata pelajaran pada masa KTSP, hal ini menjadikan siswa kelas 1 bergairah belajar membaca karena terdapat gambar- gambar yang menarik. Aktivitas selanjutnya guru selalu membagi bacaan dalam bentuk lirik lagu - lagu wajib yang setiap satu minggu sekali lirik lagu- lagu wajib selalu diganti, tentunya pada lirik lagu tersebut dikenalkan gambar yang berthubungan dengan lagu.Secara tidak langsung mengenalkan elemen musik pada siswa melalui nyanyian, karena di SD Negeri Banjaran Selain ada pembiasaan berdoa sebelum masuk kelas, juga ada aktivitas menyanyikan lagu-lagu wajib sesudah berdoa, bahkan dalam berdoapun bagi siswa yang belum hafal bacaan dengan melalui membaca .Karena dalam agama pun terdapat IQRO (bacalah), Jadi aktivitas membaca terjadi sejak jaman Nabi Muhammad SA W. Membaca adalah suatu keterampilan yang kompleks yang rumit, yang mencakup atau melibatkan serangkaian keterampilanketerampilan yang lebih kecil. Dengan kata lain membaca juga merupakan suatu aktivitas.

Keterampilan membaca mencakup tiga komponen, yaitu: (1). Pengenalan terhadap aksara serta tanda - tanda baca,(2). Korelasi aksara beserta tandatanda baca dengan unsur-unsur linguistik yang formal, dan (3)hubungan lebih lanjut dari (1) dan(2) dengan makna atau meaning.

Pengenalan terhadap aksara serta terhadap tanda-tandabaca merupakan suatu keterampilan atau aktivitas untuk mengenal bentuk- bentuk yang disesuaikan dengan mode yang berupa gambar, gambar di atas suatu lembaran, lengkunganlengkungan, garis- garis dan titik- titik dalam hubungan berpola yang terhitung rapi.

Wiryodijoyo menyatakan bahwa membaca sebagai suatu keterampilan dapat dibedakan menjadi tiga macam yaitu: keterampilan mengenal kata, keterampilan pemahaman dan keterampilan belajar.

Keterampilan mengenal kata dipelajari di kelas-kelas permulaan sekolah dasar. Pada pokoknya keterampilan ini berupa keterampilan membaca kata-kata dasar, 
keterampilan dasar kata-kata berimbuhan,keterampilan membaca katakata majemuk, keterampilan membaca kelompok kata.

2. Meningkatkan pemahaman siswa kelas 1 semester 1 SD Negeri Banjaran pada mata pelajaran Bahasa Indonesia dengan media gambar dua dimensi di antaranya dilakukan dengan mengembangkan kemampuan bahasa. Secara garis besar keterampilan membaca diikhtisarkan sebagai berikut. (1) pemahaman sebenarnya yaitu pemahaman terhadap keterampilan-keterampilan dasar dan mendapatkan arti dari konteks, (2) Keterampilan menafsirkan , (3) keterampilan evaluasi.

Keterampilan belajar pada "membaca" dikenal sebagai keterampilan fungsional. Pada umumnya membaca pada pokok masalah tertentu lebih sulit dari pada membaca yang dilakukan sehari- hari.

Membaca 15 menit sebelum jam pelajaran pertama dimulai, siswa wajib membaca buku cerita fiksi maupun non fiksi dengan kata lain buku non pelajaran. Kegiatan ini perlu mendapat dukungan dari seluruh warga sekolah dan masyarakat karena termasuk kegiatan yang positif, walaupun sedikit menyita waktu dan melelahkan karena guru kelas satu harus setiap hari menyiapkan buku-bukunya karena diusia kelas satu, siswa belum bisa diatur dalam segi kerapihan setiap selesai membaca.dalam kurun waktu setahun ini yang kita kenal dengan Gerakan Literasi Nasional (GLS) berawal dari keluarnya Permendikbud No 23 tahun 2015.GLS ramai- ramai diimplementasikan di sekolah. yang setiap hari dijadikan sebagai pembiasaan oleh siswa kelas 1 Sekolah Dasar Negeri Banjaran khususnya, dijadikan acuan pemahaman siswa terhadap pelajaran Bahasa Indonesia, yang sekarang dirasakan di Sekolah Dasar Negeri Banjaran dirasakan minat membaca mengalami degadrasi. Penurunan total. Gejala ini secara kasat mata dapat dilihat dari masih lemahnya kemampuan siswa dalam mengemukakan pendapat menyusun kalimat,sementara kita tahu bahwa wawasan yang luas bisa didapat darikegiatan membaca. Korelasinya jelas bahwa kegiatan menulis bisa muncul ketika seseorang banyak membaca. Artinya dalam otaknya telah tersimpan materi hasil rekaman saat kegiatan membaca berlangsung, apalagi bila membaca dengan menggunakan media gambar dua dimensi. Siswa kelas satu setelahnya diberlakukan gerakan LITERASI sekarang minat bacanya semakin meningkat mengingat hal demikian kiranya tidak berlebihan bila harus dilakukan upaya konstan, berupa aktivitas yang menggerakkan semua komponen sehingga minat membaca dan menulis muncul dengan sendirinya.Dalam hal ini Gerakan Literasi Nasional hakikatnya hanya berupa stimulant untuk tumbuhnya minat membaca dan menulis. Walaupun seolah-olah gaya memaksamenggiring siswa ketagihan membaca sekaligus pula nanti ketagihan menulis. Tentu membutuhkan waktu yang lama dalam menjadikan membaca untuk sebuah hobi atau kebiasaan. Implementasi GLS sepertinya sesuatu hal yang mudah, sepertinya gampang menggiring siswa untuk melakukan kegiatan membaca. Ada persoalan yang harus diperhatikan oleh pihak sekolah, bahwa kegiatan sederhana ini perlu didukung oleh sumber daya manusia (SDM) dan sarana prasarana memadai. Keberlangsungan kegiatan literasi tidak akan berjalan lancar jika kesediaan bahan bacaan terbatas. Saya sebagai guru kelas satu mencoba untuk memindahkan buku-buku dari perpustakaan, karena tidak mungkin untuk selalu dapat mengawasi membaca anak di perpustakaan setiap hari, tentunya bukubuku yang memuat gambar dua dimensi baik cerita fiksi maupun non fiksi. Saya hanya bisa mengkondisikan siswa di kelas satu saja karena tidak mungkin perpustakaan dapat menampung seluruh siswa SD Negeri Banjaran di perpustakaan. Melayani siswa dalam program literasi ini 
dengan satu persatu setiap anak dipanggil untuk membaca dengan ditunjukkan satupersatu buku cerita kepada siswa, karena siswa kelas satu masih tergolong masa bermain jadi harus betul-betul siswa dilayani sebaik mungkin, karena tersinggung sedikit saja bisa mematahkan semangat anak untuk membaca dan hilangnya percaya diri. Kendala yang dihadapi dalam GLS ini adalah diantaranya mungkinkah setiap hari seorang guru hanya menggunta-ganti buku untuk membaca? Kemudian mengawal siswa supaya membaca bersungguh-sungguh dalam membaca? Dalam kegiatan pembiasaan literasi yang kami rasakan di sekolah banyak kendala yang dihadapi oleh siswa kelas satu, di antaranya adalah masih belum semua siswa kelas satu bisa membaca lancar, hal ini membuat sulit pada pemahaman siswa dalam membaca. Masih rendahnya minat siswa kelas satu untuk membaca sehingga kesannya seolaholah dipaksakan. Haruskan guru setiap hari memaksakan keadaan demikian? Dalam meningkatkan pemahaman siswa dalam membaca guru harus senantiasa bersabar menghadapi cara membaca anak yang bervariasi tersebut, karena siswa sifatnya unik mempunyai karakteristik tersendiri. Kalau seorang guru selalu bersabar dalam menghadapi anak dalam membaca pastinya tujuan pendidikan akan tercapai. Walaupun dirasakan guru seolah-olah mempunyai beban berat harus mempersiapkan diri untuk mengajar setelah literasi. Tapi kalau setiap guru beranggapan literasi bukanlah suatu beban tapi berjalan bagaikan air,maka kegiatan literasi ini akan menjadi kenikmatan tersendiri dan akan menjadikan suatu hobi atau kesenangan sehingga kalau siswa sudah senang terhadap membaca pasti pemahaman akan isi bacaan pun akan terwujud. Hal ini membantu pada pembelajaran Bahasa Indonesia.

$$
\text { (Tarigan, 1979;36) juga }
$$
mengatakan dalam membaca intensif yang diutamakan bukanlah hakekat keterampilan- keterampilan yang tampak atau hal-hal yang menarik perhatian, melainkan hasil- hasilnya; dalam hal ini suatu pengertian suatu pemahaman yang mendalam serta terperinci terhadap teks yang dibaca. Tujuan utama dalam membaca intensif adalah untuk memperoleh sukses dalam pemahaman penuh terhadap argumen-argumen yang logis, urutan-urutan retoris atau pola-pola teks, pola pola simbolisnya; nada-nada tambahan yang bersifat emosional dan social, pola-pola sifat dan tujuan sang pengarang, dan juga sarana-sarana linguistic yang dipergunakan untuk mencapai tujuan. Dari pendapat Tarigan tersebut dapat disimpulkan GLS sangat sesuai diterapkan pada peserta didik untuk pembelajaran Bahasa Indonesia.

(Widyamartaya ， 1992;60) berpendapat membaca secara intensif diperlukan untuk memperoleh informasi yang lebih bermutu, lebih berbobot, lebih kental yang lebih merupakan kebulatan (keseluruhan). Membaca intensif menuntut kita untuk mewujudkan pemikiran saling hubung (relational thinking). Kemampuan berpikir secara saling hubung perlu dan penting untuk mempelajari isi buku secara mendalam dan terperinci. Dari pendapat Widyamartaya tersebut relevan dengan program literasi karena didalamnya mencakup unsur tersebut. Dengan literasi akan meningkatkan minat baca siswa, dan kalau sudah tumbuh minat baca maha siswa akan senang membaca dan penguasaan materi membaca dan membuat kalimatpun akan meningkat.

Berdasarkan pendapat di atas, dapat disimpulkan bahwa keterampilan membaca adalah suatu keterampilanyang kompleks karena terdiri atas beberapa komponen yang tidak dapat dipisahkan satu sama lain. Komponen -komponen tersebut membentuk satu kesatuan yang saling melengkapi . Komponen utama yang tercakup dalam komponen membaca adalah (1) pengenalan terhadap aksara, kata- kata dan tanda baca yang biasanya dipelajari pada kelas permulaan, dan (2) pemahaman terhadap kata , kelompok kata 
dan kalimat untuk kemudian menafsirkan suatu makna.

Pengenalan terhadap aksara, kata- kata dan tanda baca yang biasanya dipelajari pada kelas permulaan disajikan dalam berbagai bentuk penyajian, agar siswa kelas satu segera menguasai materi yang dibaca tentunya dengan dibantu dengan media gambar dua dimensi . Contohnya pengenalan terhadap aksara ditujukan kepada siswa dimulai dari cara menulis aksara atau huruf dimulai sejak dini agar nantinya siswa terbiasa menulis ejaan yang benar, Ejaan adalah salah satu faktor penentu arti suatu kalimat,ejaan merupakan dasar bagi suatu keterampilan menulis, tulisan atau karangan yang menggunakan ejaan akan lebih mudah dipahami. Dan kalau guru benar- benar memperhatikan cara anak menulis dapat dipastikan siswa akan menulis sesuai dengan ketentuan yang berlaku, dan bila siswa dalam cara menulis memegang pinsil betul, dapat dipastikan menulis tegak bersambungnya akan benar. Pengenalan kata-kata akan menambah wawasan peserta didik akan kosa kata apalagi bila siswa dikenalkan tanda baca yang biasanya juga dipelajari dikelas permulaan.Siswa kelas satu dalam membaca sambil dikenalkan penggunaan tanda baca. Yang dimaksud dengan ejaan adalah keseluruhan aturan bagaimana melambangkan bunyi ujaran dan bagaimana hubungannya antara lambanglambang itu (pemisahan dan penggabungannya dalam suatu bahasa)." Secara teknis yang dimaksud dengan ejaan adalah penulisan huruf, penulisan kata, dan penulisan tanda baca"( Arifin,1989: 25)

Yang dimaksud dengan menulis menurut Tarigan adalah : ...menulis adalah merupakan suatu keterampilan berbahasa yang dipergunakan untuk berkomunikasi secara tidak langsung, tidak secara tatap muka dengan orang lain .Menulis merupakan suatu kegiatan yang produktif dan ekspresif. Dalam kegiatan menulis ini maka seorang penulis haruslah trampil memanfaatkan grafologi, struktur bahasa, dan kosa kata. Keterampilan menulis ini tidak akan datang secara otomatis, melainkan harus melalui latihan dan praktik nyang banyak dan teratur (Tarigan, 1985:3-4).

Selanjutnya pada halaman berikutnya, Tarigan mengemukakan, yaitu :

Menulis ialah menurunkan atau melukiskan lambang-lambang grafik yang melambangkan suatu bahasa yang dipahami oleh seseorang, sehingga orang lain dapat membaca lambang-lambang grafik tersebut. Kalau mereka memahami bahasa dan gambaran grafik itu, gambaran atau lukisan mungkin dapat menyampaikan makna, tetapi tidak menggambarkan kesatuan-kesatuan bahasa (Tarigan, 1985: 21)

Sedangkan menurut Suhendar, menulis atau mengarang adalah suatu proses berbahasa untuk mengemukakan pikiran, perasaan, dan kehendak kepada orang lain dengan menggunakan bahasa tulis. Atau menulis merupakan proses perubahyan wujud pikiran/ gagasan/ perasaan dan sebagainya. Wujud lambang atau tanda yang bermakna ( Suhendar, 1983: 13)

Dalam membaca permulaan pada siswa kelas 1 juga dikenalkan penulisan huruf kapital, hal ini agar siswa memahami makna suatu kalimat dengan menggunakan Ejaan Bahasa Indonesia yang Disempurnakan.

1. Pemahaman terhadap kata, kelompok kata dan kalimat untuk kemudian menafsirkan suatu makna dilakukan dengan berbagai cara, di antaranya adalah tulisan atau karangan yang menggunakan ejaan akan lebih mudah dipahami, apalagi kata- kata yang digunakan menggunakan makna lugas karena disesuaikan dengan tingkatan usia siswa kelas 1. Dalam membaca pada usia permulaan, bacaan yang dibaca harus konkrit supaya siswa tidak mempunyai kesan ambigu atau verbalisme. Tak lepas dari apa yang dibaca oleh siswa supaya mudah dipahami menggunakan media gambar dua dimensi, hal ini untuk menambah daya ingat siswa 
dengan kata lain memori siswa akan lebih lama tersimpan jika dibantu dengan media gambar dua dimensi, dan pemahaman akan materi akan meningkat.dengan selalu banyak membaca atau sering membaca, siswa akan terbiasa membaca dan seolah olah membaca merupakan agenda rutin atau kebiasaan baik yang tertanam sejak usia Sekolah Dasar (07-12 tahun). Peserta didik akan merasa terdorong untuk belajar, jika kegiatan belajar tersebut sesuai dengan minatnya.dan peserta didik yang mempunyai sifat positif terhadap sesuatu kegiatan akan berusaha sebisa mungkin menyelesaikan kegiatan tersebut sebaikbaiknya. Peserta didik mempunyai kebutuhan tertentu dan akan berusaha melakukan kegiatan apapun sesuai kebutuhannya. Motivasi ini timbul dari dalam diri peserta didik tanpa adanya paksaan dorongan dari orang lain. Motivasi pada dasarnya memang sudah ada di dalam diri setiap peserta didik, tinggal bagaimana cara seorang guru dapat menumbuhkan motivasi tersebut pada motivasi yang selalumembaca, membaca dan membaca hingga membaca menjadi suatu kebutuhan atau hobi.Aktivitas membaca ataupun menulis yang dilaksanakan oleh anak didik tidak terlepas dari adanya motivasi, dimana motivasi tersebut erat kaitannya dengan tujuan. Terkait dengan hal tersebut, secara umum 4 fungsi motivasi bagi peserta didik adalah:

\section{Mendorong berbuat}

Dengan diberi contoh cara membaca yang baik oleh guru, maka akan memotivasi siswa untuk membaca. Motivasi mendorong peserta didik untuk berbuat. Artinya motivasi merupakan penggerak atau motor yang melepaskan energi peserta didik.

\section{Menentukan arah perbuatan}

Motivasi berfungsisebagai penentu arah perbuatan, yakni ke arah tujuan yang hendak dicapai oleh peserta didik. Dalam pelaksanaan membaca harus dimotivasi oleh semua unsur yang terkait dalam pembelajaran tersebut, baik guru, kepala sekolah ataupun orang tua harus memotivasi siswa kea rah belajar,tidak ada salahnya seorang guru memberi contoh membaca yang baik kepada siswa. Bahkan sebagai tindaki lanjut di rumah, orang tua selalu mendampingi anaknya belajar membaca yang baik, yang sesuai dengan tanda baca,intonasi yang tepat, supaya buku yang dibaca isinya dapat difahami.

Menyeleksi perbuatan

Menentukan berbagai perbuatan yang harus dikerjakan oleh peserta didik guna mencapai tujuan, dengan menyisihkan berbagai perbuatan yang tidak bermanfaat.Dalam kegiatan ini guru selalu mengawasi saat anak membaca ataupun menulis. Selalu memberi peringatan pada anak yang ngobrol, bandel, dan anak yang tidak mau mengikuti pembelajaran.

Pendorong usaha dan pencapaian prestasi

Peserta didik melaksanakan segala sesuatu karena adanya motivasi. Motivasi tersebut merupakan pemicu bagi pencapaian prestasi, contohnya bagi murid kelas 1 adanya suatu perlombaan calistung, dan membaca merupakan faktor penting dalam perlombaan tersebut. Membaca teknik diterapkan pada siswa dengan kecepatan permenitnya dihitung tiap kata, juga tanpa mengabaikan intonasi dan tanda baca. Selain membaca teknik, penulisan huruf tegak bersambung pun dilombakan, dan aspek yang dinilainya adalah kerapihan dan kesesuaian dengan Ejaan Bahasa Indonesia yang Disempurnakan. Jadi guru kelas satu dituntut untuk selalu mengawasi dan membetulkan cara siswa menulis yang baik dan benar. Hal ini untuk memicu pendorong usaha dan pencapaian prestasi siswa dalam penulisan huruf tegak bersambung, karena kalau siswa salah dalam menulis, walaupun bentuknya sama maka hasilnya akan berbeda. Penulisan huruf tegak bersambung yang baik dan benar akan menjadi modal dasar bagi siswa dikemudian hari menjadi seorang penulis atau pengarang yang selalu mementingkan 
kaidah bahasa Indonesia yang dijadikan pedoman dalam penulisan suatu karangan.Sungguh suatu hal yang memprihatinkan karena masih banyak siswa yang kurang memperhatikan terhadap Ejaan yang Disempurnakan, yang dipakainya bukan bahasa Indonesia Baku tapi bahasa gaul. Bahkan contohnya penulisan huruf "a" juga seperti terbalik. Ini hal yang harus kita cermati bersama sebagai seorang guru berkewajiban membetulkan penulisan huruf sesuai dengan kaidah bahasa Indonesia yang Disempurnakan. Alangkah baiknya sebagai guru kelas 1 untuk dengan rajin memberi contoh penulisan huruf tegak bersambung pada peserta didik. Pasilitasi pesetra didik dengan buku yang bergaris untuk penulisan huruf tegak bersambung, bahkan sediakan papan tulis bergaris, karena setelah diamati, banyak penulisan yang semestinya setengah pada garis bawah pada huruf "g,y.p" tidak sesuai dengan kaidah bahasa Indonesia yang Disempurnakan. Dalam menulis harus disertai dengan penggunaan ejaan yang tepat, sehingga pembaca akan lebih mudah memahami tulisan kita. Oleh karena itu, pengajaran Ejaan yang Disempurnakan perlu diajarkian kepada para siswa sekolah dasar smpai dengan para mahasiswa di perguruan tinggi. Sejak siswa mulai di sekolah dasar harus sudah dibiasakan oleh gurunya untuk menulis atau membuat karangan dengan menggunakan ejaan yang tepat. Sungguh suatu hal yang sangat membanggakan bila semua guru baik guru kelas 1,2,3,4,5 dan 6 mendukung cara seperti ini. Bahkan dalam kurikulum 2013 yang dilaksanakan di SD Negeri Banjaran, keterlibatan orang tua dalam mendampingi peserta didik sangatlah diharapkan, terutama dalam pengerjaan tugas rumah, orang tua selalu mendampingi anaknya dalam pengerjaan PR tersebut. Jadi dengan demikian tujuan pendidikan yang kita harapkan pasti akan tercapai bila terdapat hubungan kerja sama antara guru dan orang tua.

Pengenalan kata, kelompok kata dan kalimat akan lebih mudah dipahami bila dibantu dengan media gambar dua dimensi. Siswa akan terbiasa membuat kalimat sejak kelas1 SD walaupun hanya kalimat sederhana. Dalam pengenalan kata, kelompok kata akan memudahkan siswa membuat kalimat. Hal ini juga sering dilakukan oleh siswa SD Negeri Banjaran sejak kelas 1 sampai kelas 6. Kita sebagai seorang guru berkewajiban juga menilai hasil kerja siswa, supaya tumbuh rasa percaya diri pada siswa dan siswa akan merasa bangga hasil karyanya dihargai, dan beri reward pada siswa yang paling baik dalam karyanya atau dalam membuat kalimat, supaya siswa tumbuh rasa percaya dirinya. Siswa berlomba untuk menyelesaikan judul buku yang dibacanya melalui literasi, yang terbanyak diberi reward.

\section{Penutup}

Berdasarkan paparan tersebut, dapat ditarik kesimpulan sebagai berikut .

Terdapat hubungan yang signifikan antara aktivitas pesera didik dalam aktivitas siswa sehari-hari dalam Peningkatan Penguasaan Materi Membaca dan Membuat Kalimat Melalui Media Gambar Dua Dimensi Tema Kegiatanku Pada Siswa Kelas 1 SD Negeri Banjaran dengan pemahaman siswa terhadap materi pembelajaran bahasa Indonesia dengan beberapa tahapan. Kegiatan penelitian ini adalah penelitian terapan dan berupa peneliian untuk peningkatan kualitas pembelajaran . penelitian ini menggunakan pendekaan penelitian tindakan kelas. beberapa hal yang patut digaris bawahi sebagai simpulan adalah :

1. Tata cara penggunaan strategi media gambar dua dimensi untuk meningkatkan kemampuan penguasaan dan pemahaman siswa terhadap materi pembelajaran bahasa Indonesia dengan beberapa tahapan. Tahapan yang dimaksud adalah: (a) persiapan (b) aktivitas belajar mengajar dan (c) tahap pelaksanaan tindakan.

2. Setelah siswa diberi tindakan sebanyak satu kali (dua siklus), kemampuan 
menguasai atau pemahamannya terhadap materi baik pada pada mata pelajaran bahasa Indonesia denganmedia gambar dua dimensi tergolong berkategori baik dan sangat (terbaik) tercatat lebih dari $75 \%$. Berdasarkan tabel 3 dan 4 setelah siklus kedua dilaksanakan, yang memperoleh skor rerata $8-7$ sebanyak 22 orang siswa $(90,47 \%)$. Artinya kemampuan penguasaan materi tergolong sangat baik. Sedangkan berdasarkan tabel 2, siswa yang memperoleh skor rerata $10-9$ dan 8 sebanyak 3 orang siswa $(90,47 \%)$. Artinya siswa sudah menguasai materi dengan baik.

3. Eksposisi ini menunjukkan tingkat keberhasilan yang telah ditandai dengan telah tercapainya indikator keberhasilan penelitian, yakni siswa yang memiliki kemampuan penguasaan materi dan pemahaman sangat baik minimal $75 \%$. Sementara itu, berdasarkan data yang diperoleh ditujukan bahwa siswa yang menguasai materi di atas $70 \%$ yaitu $90,47 \%$.

Adapun saran yang disampaikan adalah:

1. Agar memiliki nilai guna yang optimal,semua hasil penelitian ini harus segera disosialisasikan dan ditindaklanjuti. Terutama yang berhubungan dengan bagaimana memanfaatkan berbagai strategi pembelajaran, salah satunya adalah dengan media gambar dua dimensi

2. Guru-guru sekolah dasar harus terus menggiatkan pelaksanaan penelitian tindakan semacam ini, sehingga nantinya akan diperoleh berbagai strategi dalam upaya peningkatan kualitas pembelajaran, yang pada akhirnya akan meningkatkan kualitas dan kredibilitas suatu sekolah.

3. Guru Bahasa Indonesia harus memberikan penilaian khusus terhadap tulisan siswa, karena dengan cara demikian siswa akan sel;alu memperhatikan tulisannya dengan berpedoman kepada ejaan bahasa Indonesia yang Disempurnakan.

4. Dengan adanya Gerakan Literasi Nasional (GLS), Maka sekolah hendaknya menyediakan buku-buku teks yang memadai dengan jumlah siswa, baik fiksi maupun non fiksi dan guru senantiasa membiasakan diri menggunakan media pendidikan dalam proses pembelajaran.

5. Guru harus mampu menciptakan suasana pembelajaran yang memberdayakan siswa .untuk menciptakan suasana yang dinamis dan menggairahkan dalam belajar guru atau fasilitator perlu memahami dan dapat menerapkan aspek-aspek pembelajaran kuantum sebagai berikut: niat kuat seorang guru dan berpandangan positif, menjalin rasa simpati dan saling pengertian, keriangan dan ketakjuban, mau mengambil resiko, menunjukkan rasa saling memiliki dan menunjukkan keteladanan (buah karya dari Bobby De Porter (1999).

\section{Daftar pustaka}

Depdikbud. 1993. Tatabahasa Baku Bahasa Indonesia .Jakarta : Depdikbud-----------.1995. Kamus Besar Bahasa Indonesia .Jakarta :Depdikbud Elang,Kusnadi.2002.Materi Pokok Pembelajaran Ilmu Pengetahuan Alam Jakarta : Universitas terbuka.

Jehan, W. George 1997. Teknik berbicara yang meyakinkan dan efektif. Jakarta: Gunung Jati

N.K.Roetiyah, 2001. Strategi Belajar Mengajar. Jakarta:Rineka Cipta

Nurhadi dan Gerrad Senduk .2003. Pembelajaran Kontekstual dan penerapannya dalam KBK. Malang : Universitas Malang

Sibarani, R. 1992 Hakikat Bahasa. Bandung : PT. Aditya Bakti 
Taufik, Agus. 2002. Teori-teori Belajar dan Implikasi dalam Pembelajaran. Jakarta :

Universitas Terbuka.2005. Materi Pokok Penelitian Tindakan Kelas. Jakarta : Universitas Terbuka 